\title{
The Determinants of Dividend Payout: Evidence from Private Banks in Ethiopia
}

\author{
Workneh Dilie Kassie \\ Lecturer in Accounting and Finance, Mekdela Amba universty \\ PO box-Mekane Selam, Ethiopia
}

\begin{abstract}
The main objective of this study was investigating factors that determine the dividend payout of private commercial banks in Ethiopia under the study period covering from 2009 to 2017. A balanced panel data set from national bank of Ethiopia and ten private commercial banks annual report was used and analyzed through fixed effects panel data regression technique. Dividend payout was used as a dependent variable and the independent variables covered under this study were both bank specific (profitability, leverage, liquidity, size and last year dividend payout) and macroeconomic factors (inflation rate, real GDP growth rate and foreign exchange rate). The finding shows that from bank specific factor; profitability, liquidity, bank size and last year dividend payout have statistically significant positive effect on dividend payout while leverage shows insignificant positive effect for dividend payout. From macroeconomic variables inflation rate have a positive effect, but the real GDP growth rate, and foreign exchange rate have a negative effect and foreign exchange rate is the only significant macroeconomic factor for dividend payout. The results of this study have delivered some insights on the effects of both bank specific and macroeconomic factor for dividend payout of private commercial banks in Ethiopia and managements and board of directors of those banks need to consider these variables while designing their dividend payout. In addition, government body specially financial sector should have to consider the effet of macroeconomic variables on dividend payout when they are making a policy about macroeconomic issues.
\end{abstract}

Keywords: Commercial Banks, Bank Specific determinant, dividend payout and macroeconomic determinants.

DOI: $10.7176 /$ RJFA/12-3-03

Publication date: February $28^{\text {th }} 2021$

\section{Introduction}

Banks in Ethiopia are an essential part of our economic system. The owners of those banks are Shareholders, and the bank distributes a portion of its earnings to those shareholders which is called dividend. Ishtiaq (2016) described it as the best way of communication for banks to its shareholders.

In banking business, finance managers mostly face two operational decisions at the beginning. What real assets the firm should acquire? (Investment decision) and how these assets should be financed? (financing decision). However, another decision is raised when the firm begins to generate profits which is concerned with whether the firm distributes proportion of earned profits in the form of dividends or should reinvest back into the business (Al-Malkawi, Rafferty, \& Pillai, 2010; Alam \& Hossain, 2012). Such a decision of the firm about how much earnings should be distributed, how stable the distribution should be, and how much should be retained is the a dividend payout decision (Chekole, 2016).

Different shareholders have different interest in relation to dividend payout. According to Dhanani (2005) certain shareholders may prefer cash dividends while others may prefer capital gain. Therefore, based on the shareholders' preferences, managers and board of directors of the company should decide carefully that how much amount of earnings should be distributed to shareholders and how much portion of earnings should be reinvested in the business. Researchers in corporate finance have developed several theories to explain the dividend payout of firms and their determinants. Profitability, liquidity, risk, leverage, age, financial performance, size, previous dividend and capital adequacy are included in most of prior literatures. But the finding relation to the effect of those variables on dividend payout is inconsistent across different researchers.

Lintner (1956) who found that dividend payout are the function of a firm's profit and last year dividend. Who was also supported by different researchers ( Pruit \& Gitman 1991, and Gill et al., 2009). But in contrary to this Elias (2015) found the profitability effect for dividend payout is insignificant and Chekole (2016) said it has negative significant effect. Muhammed (2012) founds liquidity as a significant positive factor for dividend payout, but Simegn (2013) found it in the other sign and Elias (2015); Chekole (2016) and Henok (2016) stated it as a negative and insignificant factor for dividend payout of banks. Higgins (1981) state that firm size has a significant positive effect, but Elias (2015) and Henok (2016) found out its effect is negative and significant.Collins, Saxena \& Wansley (1996) found that financial leverage affects firms' dividend payout decision, while Elias (2015) found it has a negative insignificant effect.

Since there is continuous change in globalization, regulation, parallel competition and volatile market dynamics, the factor affecting dividend payout in today might differ from the factors for yesterday. So conducting a research on such issue is still important. In Ethiopia different academicians conduct their research on the 
determinants of commercial bank dividend payout such as; Theodros (2011); Simegn (2013); Elias (2015) and Chekole (2016). But as to the researchers' knowledge all of them concentrate on bank specific factors of dividend payout. That is why the researcher in this research tries to fill such a gap in the literature by incorporating additional macro-economic factors such as inflation rate, real GDP growth rate and foreign exchange rate.

\subsection{Research objective}

\subsubsection{General Objective}

The jeneral objective of the study is to investigate the major determinants of the dividend payout in case of private commercial banks in Ethiopia.

\subsubsection{Specific objectives}

$>$ To investigate the effect of bank specific factors over the dividend payout of private commercial banks in Ethiopia.

$>$ To investigate the effects of macroeconomic factors over the dividend payout of private commercial banks in Ethiopia.

\subsection{Hypothesis of the study}

Research hypothesis are developed mainly by reviewing different literature so as to support the theory by empirical evidence. The researcher reviewed several imperical literature which is presented in the literature review part of this paper Therefore, as per the review of prior literature related to the study area, the researcher has formulated the following research hypothesis.

Ho. There is a significant positive relationship between profitability and dividend payout of private commercial banks in Ethiopia.

Ho. There is a significant negative relationship between leverage and dividend payout of private commercial banks in Ethiopia.

Ho. There is a significant positive relationship between liquidity and dividend payout ofprivate commercial banks in Ethiopia.

Ho. There is a significant positive relationship between Bank size and dividend payout of private commercial banks in Ethiopia.

Ho. The last year dividend has a positive significant relationship with a dividend payout of private commercial banks in Ethiopia.

Ho. There is a significant negative relation between Inflation rate and dividend payout of private commercial banks in Ethiopia.

Ho.There is a significant positive relationship between real GDP growth rate and dividend payout of private commercial banks in Ethiopia.

Ho. There is a significant negative relationship between Exchange rate and dividend payout of private commercial banks in Ethiopia.

\section{Research Methodologys}

\subsection{Research Design}

The major objective of this paper is to investigate both bank specific and macroeconomic factors affecting dividend payout in Ethiopian private commercial banks. So the researcher follow quantitative approach and a primarily explanatory type of research is used to establish a relationship between a number of explanatory variables and dividend payout. On the other hand before testing the relationship between the dependent and independent variables, all the variables included in the study need to be identified and presented. Therefore descriptive type of studies is combined with explanatory study. According to Marshal (1996) the goal of quantitative research is to test a pre-determined hypothesis and to produce general results. By means of statistical methods, the results of quantitative analysis can prove or disprove hypotheses. Conclusions made from the analysis of quantitative data show how many are affected and where is the greatest area of impact.

\subsection{Population and sample size}

In this study a total population are all private banks in Ethiopia and a non-random sampling technique was applied, which is purposive or judgmental sampling based on the availability of 9 years data from all private commercial banks. List of banks that are included in the sample are presented in the following table clearly. Those sample present $62.5 \%$ of total population. 
Table2.1: list private commercial banks(sample size)

\begin{tabular}{|l|l|l|l|}
\hline No & Name Banks & Starting year & Age of banks \\
\hline $\mathbf{1}$ & Awash International Bank S.C & 1994 & 24 \\
$\mathbf{2}$ & Dashen Bank S.C & 1995 & 23 \\
$\mathbf{3}$ & Wegagen Bank S.C & 1997 & 21 \\
$\mathbf{4}$ & United Bank S.C & 1998 & 20 \\
$\mathbf{5}$ & Nib International Bank S.C & 1999 & 19 \\
$\mathbf{6}$ & Cooperative Bank of OromiaS.C & 2004 & 15 \\
$\mathbf{7}$ & Lion International Bank S.C & 2006 & 13 \\
$\mathbf{8}$ & Oromia International Bank S.C & 2008 & 10 \\
$\mathbf{9}$ & Zemen BankS.C & 2008 & 10 \\
$\mathbf{1 0}$ & Birhan International Bank S.C & 2009 & 9 \\
\hline Number of sample(10) /total population(16) $=\mathbf{6 2 . 5 \%}$ 0f total population \\
\hline
\end{tabular}

Source: National bank of Ethiopia, 2017

\subsection{Data Types and Source}

In this study, the researcher use 10 private commercial bank financial data and national bank of ethhiopia (NBE) annual reports for subsequent 9 recent years, which covers the period from 2009 to 2017. Therefore, the researcher used secondary data only. Published secondary data were collected from selected private banks and from national bank of Ethiopia. In this the annual audited financial report of national bank of Ethiopia and some older private commercial banks are collected from their head office.

\subsection{Method of Data Analysis}

Descriptive statistics like mean, minimum, maximum and standard deviation were used to organize, summarize, and describe observations and to compare variables numerically. Second Correlation analysis is used to measure the degree of association between the dependent and independent variable. It also used to indicate the direction and the strength of association between independent and dependent variables (Simegn, 2013). Finally the regression analysis is used to see the relationship between the explanatory variables and the dependent variables and to test the hypothesis. The analysis was accomplished by using quantitative data analysis tool STATA version 12 software.

Table2.2: Variable description and their expected sign

\begin{tabular}{|l|l|l|l|l|}
\hline No & Variable & \multicolumn{1}{|c|}{ Symbol } & \multicolumn{1}{|c|}{ Description } & Ex-sign \\
\hline $\mathbf{1}$ & Profitability & PRO & PAT/shareholders' equity & + ve \\
$\mathbf{2}$ & Leverage & LEV & Total debt/total asset & - ve \\
$\mathbf{3}$ & Liquidity & LIQ & Current asset/current liability & + ve \\
$\mathbf{4}$ & Bank size & SIZ & Natural logarithm of total asset & $+\mathrm{ve}$ \\
$\mathbf{5}$ & Last dividend payout & LDP & Last year dividend payout rate & $+\mathrm{ve}$ \\
$\mathbf{6}$ & Inflation rate & INR & Annual inflation rate by NBE & $-\mathrm{ve}$ \\
$\mathbf{7}$ & Real GDP growth rate & GDPGR & GDP last- GDP this/GDP last year & $+\mathrm{ve}$ \\
$\mathbf{8}$ & Exchange rate & EXR & annual exchange rate Birr/USD & $-\mathrm{ve}$ \\
\hline
\end{tabular}

Source: prior researchers (Mundati, 2011; Theodros, 2011; Elias, 2013, knife, 2015 and Chekolle, 2016)

\subsection{Model specification}

The panel regression equation differs from a regular time-series or cross-section regression by the double subscript attached to each variable. The general form of the panel data model can be specified more compactly as:

$$
\mathrm{Yi}, \mathrm{t}=\alpha_{\mathrm{i}}+\beta \mathrm{Xi}, \mathrm{t}+\varepsilon \mathrm{i}, \mathrm{t}
$$

From this $\mathrm{i}$, represent the cross-sectional dimension

$$
t \text {, representing the time-series dimension }
$$

Yi,t represents the dependent variable ratio

$\mathrm{Xi}, \mathrm{t}$ contains the set of explanatory variables; and

$\alpha i$ is constant over time $t$ and specific to the individual cross-sectional unit $i$.

Thus dividend payout rate is expressed as a function of bank specific and macro-economic factors. $D P O=$ $f$ (pro, liq, lev, ldpo, size, inf, gdpgr andfer)

DPOi, $\mathrm{t}=\alpha_{\mathrm{i}}+\beta_{1} \mathrm{PRO}_{\mathrm{it}}+\beta_{2} \mathrm{LEV}_{\mathrm{it}}+\beta_{3} \mathrm{LIQ}_{\mathrm{it}}+\beta_{4} \mathrm{SIZ}_{\mathrm{it}}++\beta_{5} \mathrm{LDP}_{\mathrm{it}}+\beta_{6} \mathrm{INR}_{\mathrm{it}}+\beta_{7} \mathrm{GDPGR}_{\mathrm{it}}$ $+\beta_{8} \mathrm{FER}_{\mathrm{it}}+\varepsilon_{\mathrm{it}}$

Where PRO, represents profitability 
LIQ, represents liquidity

LEV, represents leverage

SIZ, represent bank size

LDP, represents last year dividend payout

INR, represent inflation rate

GDPGR, represent real GDP growth rate

FER, represents foreign exchange rate

$\beta 1-\beta 8$, represents regression coefficients for each explanatory variable

$a i$,represents the intercept of the regression equation

$i$, represents the cross-section dimention (banks)

$t$, represents the time series dimention (years)

$\varepsilon$ represents the error term which accounts for variables affecting DPO that are not included in the model.

\section{RESULTS AND DISCUSSION}

\subsection{Descriptive analysis}

Table 4.1 provides a summary of the descriptive statistics of the dependent and independent variables for ten private commercial banks from year 2009 to 2017 with a total of 90 observations. The table shows the mean, median, standard deviation, minimum and maximum for the independent and dependent variables used in this research. It shows the average indicators of variables computed from the financial statements of each bank and national bank of Ethiopia annual report.

Table 3.1: descriptive statistics of the collected data

\begin{tabular}{|c|c|c|c|c|c|}
\hline Variable & Obs & Mean & Std.Dev. & Min & Max \\
\hline Dpo & 90 & .3625578 & .252958 & 0 & .8996975 \\
\hline Pro & 90 & .2417521 & .1171031 & -.1303632 & .5823284 \\
\hline Lev & 90 & .901583 & .8679757 & .0045529 & 8.884677 \\
\hline Liq & 90 & .8910957 & .4500407 & .0137874 & 1.942285 \\
\hline Siz & 90 & 22.35046 & 1.393415 & 18.4116 & 24.46034 \\
\hline Ldp & 90 & .3392564 & .2552299 & 0 & .8996975 \\
\hline Inr & 90 & .1551111 & .1133627 & .028 & .364 \\
\hline Gdpgr & 90 & .1037778 & .0073252 & .087 & .114 \\
\hline Fer & 90 & 19.87743 & 3.688774 & 13.5321 & 27.0321 \\
\hline
\end{tabular}

Source: STATA 12 output for summary of the collected data

\subsection{Correlation analysis}

Table 3.2: Correlation matrix for both dependent and independent variables

\begin{tabular}{|l|l|l|l|l|l|l|l|l|l|}
\hline var & Dpo & Pro & Lev & Liq & Siz & Ldp & Inr & gdpgr & fer \\
\hline Dpo & $\mathbf{1 . 0 0 0 0}$ & & & & & & & & \\
\hline Pro & $\mathbf{0 . 5 4 7 7}$ & $\mathbf{1 . 0 0 0 0}$ & & & & & & & \\
\hline Lev & $\mathbf{0 . 1 1 2 6}$ & $\mathbf{0 . 1 2 8 6}$ & $\mathbf{1 . 0 0 0 0}$ & & & & & & \\
\hline Liq & $\mathbf{0 . 5 5 2 1}$ & $\mathbf{0 . 3 2 6 4}$ & $\mathbf{0 . 0 3 1 6}$ & $\mathbf{1 . 0 0 0 0}$ & & & & & \\
\hline Siz & $\mathbf{0 . 5 5 5 4}$ & $\mathbf{0 . 4 9 6 0}$ & $\mathbf{0 . 0 6 1 4}$ & $\mathbf{0 . 6 0 8 2}$ & $\mathbf{1 . 0 0 0 0}$ & & & & \\
\hline Ldp & $\mathbf{0 . 6 9 3 8}$ & $\mathbf{0 . 3 9 3 7}$ & $\mathbf{0 . 1 6 7 3}$ & $\mathbf{0 . 4 2 0 3}$ & $\mathbf{0 . 3 7 2 6}$ & $\mathbf{1 . 0 0 0 0}$ & & & \\
\hline Inr & $\mathbf{- 0 . 0 4 1 3}$ & $\mathbf{- 0 . 1 2 9 8}$ & $\mathbf{- 0 . 0 6 3 3}$ & $\mathbf{- 0 . 0 8 1 6}$ & $\mathbf{- 0 . 1 8 0 8}$ & $\mathbf{- 0 . 1 9 3 1}$ & $\mathbf{1 . 0 0 0 0}$ & & \\
\hline Gdpgr & $\mathbf{- 0 . 0 8 7 2}$ & $\mathbf{- 0 . 0 7 1 1}$ & $\mathbf{0 . 0 5 9 4}$ & $\mathbf{0 . 0 0 9 0}$ & $\mathbf{0 . 0 0 6 3}$ & $\mathbf{0 . 1 1 8 4}$ & $\mathbf{- 0 . 4 7 6 7}$ & $\mathbf{1 . 0 0 0 0}$ & \\
\hline Fer & $\mathbf{0 . 1 6 4 0}$ & $\mathbf{0 . 1 6 7 6}$ & $\mathbf{0 . 2 1 9 1}$ & $\mathbf{0 . 3 2 7 4}$ & $\mathbf{0 . 5 1 7 0}$ & $\mathbf{0 . 3 0 6 1}$ & $\mathbf{- 0 . 5 4 1 2}$ & $\mathbf{0 . 3 3 5 3}$ & $\mathbf{1 . 0 0 0 0}$ \\
\hline
\end{tabular}

Source: STATA 12 output, correlation matrix

The above table shows the degree of correlation/association between one dependent variable (dividend payout) and eight explanatory variables (profitability, leverage, liquidity, size, last year dividend, inflation rate, real GDP growth rate and foreign exchange rate). The result shows that all bank specific variables are positively correlated with dividend payout. This indicates that when bank specific variables increase dividend payout moves in similar direction. In the other case from macroeconomic variables inflation and real GDP growth rate are negatively correlated with dividend payout. This indicates that when those macroeconomic variables increase, dividend payout goes in the opposite direction. In the other side foreign exchange rate shows a positive correlation with dividend payout. 


\subsection{Tests for model assumptions}

\subsubsection{Test for Normality}

Table 3.3: Test for normality of residuals.

Jarque-Bera Skewness/Kurtosis tests for Normality

\begin{tabular}{|l|l|l|l|l|c|}
\hline Variable & Obs & Pr(Skewness) & Pr(Kurtosis) & adj chi2(2) & Prob $>$ chi2 \\
\hline Residual & 90 & 0.5720 & 0.1936 & 2.07 & 0.3558 \\
\hline
\end{tabular}

Source: STATA 12 output, test for normality

As shown from the above table the error term is normally distributed, since the $\mathrm{p}$ is greater than 0.05 that is 0.3558 , the researcher have no reason to reject the null hypothesis which states error terms are normally distributed. The graph for normality test is also shown below.

Figure: 3.1: Histogram for normality curve

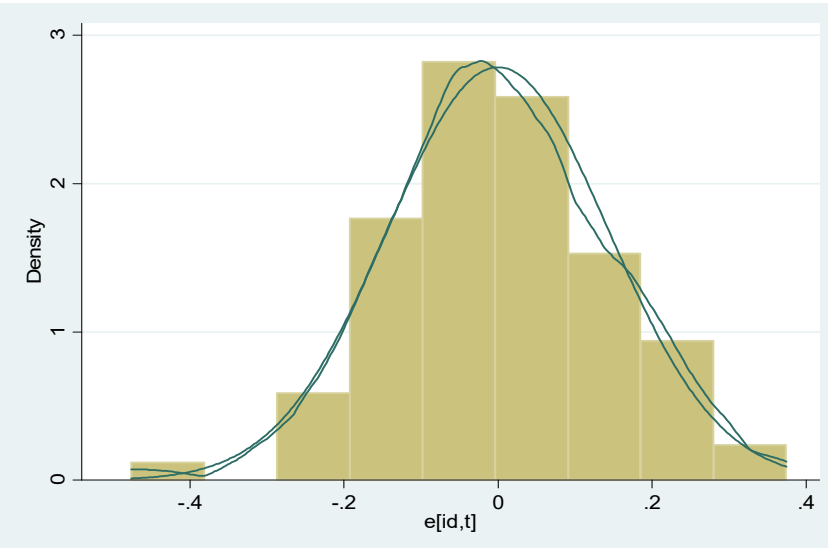

\subsubsection{Test for heteroskedasticity}

Source: STATA 12 output, histogram residual kdensity test for normality

According Breusch \& Pagan (1979) from the regressed output if the test statistic has a p - value below an appropriate significant level (0.05) then the null hypothesis of homoskedasticity is rejected and heteroskedasticity is assumed. On the other hand if $\mathrm{p}$ - value is greater than 0.05 , homoskedasticity is assumed. See table below.

Table 3.4: test for heteroskedasticity

\begin{tabular}{|l|l|}
$\begin{array}{l}\text { Breusch-Pagan / Cook-Weisberg test for heteroskedasticity } \\
\text { Ho: Constant variance } \\
\text { Variables: fitted values of dpo }\end{array}$ \\
\hline chi2(1) & 1.45 \\
Prob > chi2 & $\mathbf{0 . 2 2 8 1}$ \\
\hline
\end{tabular}

Source: STATA 12 output, test for heteroskedasticity

3.3.3 Test for Autocorrelation.

Table 3.5: test for autocorrelation

Breusch-Godfrey LM test for autocorrelation

\begin{tabular}{|l|l|l|l|}
\hline $\operatorname{lags}(\mathbf{p})$ & F & df & Prob \\
\hline 1 & 0.945 & $(1,80)$ & 0.3338 \\
\hline
\end{tabular}

H0: no serial correlation

Source: STATA 12 output, test for autocorrelation

There for as indicated from the table the p- value is above the 5\% significant level. There for we have no reason to reject the null hypothesis stated as there is no serial correlation.

\subsubsection{Test for multi- collinearity}

The values of the correlation coefficient are always between -1 and +1 . A correlation coefficient of +1 indicates that the two variables are perfectly related positively; where as a correlation coefficient of -1 indicates that two variables are perfectly related in a negative linear sense. A correlation coefficient of 0 , on the other hand indicates that there is no relationship between two variables (Gujarati, 2004). 
Table 3.6: pair with correlation matrix for independent variables

\begin{tabular}{|l|l|l|l|l|l|l|l|l|}
\hline Var & Pro & Lev & liq & Size & ldp & Inr & gdpgr & Fer \\
\hline Pro & 1.0000 & & & & & & & \\
\hline Lev & $\mathbf{0 . 1 2 8 6}$ & $\mathbf{1 . 0 0 0 0}$ & & & & & & \\
\hline Liq & $\mathbf{0 . 3 2 6 4}$ & $\mathbf{0 . 0 3 1 6}$ & $\mathbf{1 . 0 0 0 0}$ & & & & & \\
\hline Siz & $\mathbf{0 . 4 9 6 0}$ & $\mathbf{0 . 0 6 1 4}$ & $\mathbf{0 . 6 0 8 2}$ & $\mathbf{1 . 0 0 0 0}$ & & & & \\
\hline Ldp & $\mathbf{0 . 3 9 3 7}$ & $\mathbf{0 . 1 6 7 3}$ & $\mathbf{0 . 4 2 0 3}$ & $\mathbf{0 . 3 7 2 6}$ & $\mathbf{1 . 0 0 0 0}$ & & & \\
\hline Inr & $\mathbf{- 0 . 1 2 9 8}$ & $\mathbf{- 0 . 0 6 3 3}$ & $\mathbf{- 0 . 0 8 1 6}$ & $\mathbf{- 0 . 1 8 0 8}$ & $\mathbf{- 0 . 1 9 3 1}$ & $\mathbf{1 . 0 0 0 0}$ & & \\
\hline Gdpgr & $\mathbf{- 0 . 0 7 1 1}-$ & $\mathbf{0 . 0 5 9 4}$ & $\mathbf{0 . 0 0 9 0}$ & $\mathbf{0 . 0 0 6 3}$ & $\mathbf{0 . 1 1 8 4}$ & $\mathbf{0 . 4 7 6 7}$ & $\mathbf{1 . 0 0 0 0}$ & \\
\hline Fer & $\mathbf{0 . 1 6 7 6}$ & $\mathbf{0 . 2 1 9 1}$ & $\mathbf{0 . 3 2 7 4}$ & $\mathbf{0 . 5 1 7 0}$ & $\mathbf{0 . 3 0 6 1}$ & $\mathbf{- 0 . 5 4 1 2}$ & $\mathbf{0 . 3 3 5 3}$ & $\mathbf{1 . 0 0 0 0}$ \\
\hline
\end{tabular}

Source: STATA 12output,pair with correlation matrix

Furthermore, the variance inflation factor (VIF) can show the existence of a high degree of multicollinearity. According to Gujarati (2004) the benchmark to say there is a problem of multicollinearity among explanatory variables is when the mean value of variance inflation factor for each explanatory variable should be above 10 . So, according to the result the measure of VIF shows that each variable has quite below 10 and mean variance inflation factor is 1.68 . See the table below.

Table 3.7: Variance inflation factor

\begin{tabular}{|l|l|l|}
\hline Variable & VIF & $1 /$ IF \\
\hline Siz & 2.42 & 0.414064 \\
\hline Fer & 2.16 & 0.463107 \\
\hline Liq & 1.72 & 0.580753 \\
\hline Inr & 1.72 & 0.582521 \\
\hline pro & 1.53 & 0.655622 \\
\hline Ldp & 1.41 & 0.708064 \\
\hline Gdpgr & 1.37 & 0.730236 \\
\hline Lev & 1.10 & 0.908644 \\
\hline Mean VIF & 1.68 & \\
\hline
\end{tabular}

Source: STATA 12 output, variance inflation factor

3.3.4. Hausman specification test

After the basic classical linear regression model assumptions are satisfied, the researcher goes to select the appropriate panel data model by using the Hausman specification tests. The Hausman specification test is a test used to choose between the fixed effect model and random effect models. According to Hausman (1978) the null hypothesis is that the favoured model is a random effect that assumes unobserved variables are not correlated; the alternative hypothesis is that the preferred model is fixed effect. This test recommends the application of Random effect (RE) panel regression if the test statistics (chi2) p-value is above 5\%. Otherwise, the fixed effect model (FE) also called within regression is a good estimation tool.

Table 3.8: Hausman specification test result

\begin{tabular}{|c|c|c|c|c|}
\hline \multicolumn{5}{|c|}{---- Coefficients ---- } \\
\hline Variables & $\begin{array}{l}\text { (b) } \\
\text { fe }\end{array}$ & $\begin{array}{l}\text { (B) } \\
\text { re }\end{array}$ & $\begin{array}{l}\text { (b-B) } \\
\text { Difference }\end{array}$ & $\begin{array}{l}\operatorname{sqrt}\left(\operatorname{diag}\left(V_{-} b V_{-} B\right)\right) \\
\text { S.E. }\end{array}$ \\
\hline Pro & .7266785 & .3852308 & .3414477 & .1189461 \\
\hline Lev & .0240875 & .0088412 & .0152463 & .0081182 \\
\hline Liq & .1193412 & .1013891 & .0179522 & .0456974 \\
\hline Siz & .0471476 & .0490071 & -.0018595 & .0170114 \\
\hline Ldp & .2791758 & .5086423 & -.2294666 & .0653782 \\
\hline Inr & .0190601 & .0060781 & .012982 & .0177257 \\
\hline Gdpgr & -1.373901 & -2.452769 & 1.078869 & .474639 \\
\hline Fer & -.0125174 & -.0139182 & .0014008 & .0036193 \\
\hline \multicolumn{5}{|c|}{$\begin{array}{l}\text { b }=\text { consistent under Ho and Ha; obtained from xtreg } \\
\text { B = inconsistent under Ha, efficient under Ho; obtained from xtreg } \\
\text { Test: Ho: difference in coefficients not systematic } \\
\text { chi2 }(5)=(b-B)^{\prime}\left[\left(V_{-} b-V \_B\right)^{\wedge}(-1)\right](b-B) \\
=28.83 \\
\text { Prob }>\text { chi } 2=0.0000 \\
\text { (V b-V B is not positive definite })\end{array}$} \\
\hline
\end{tabular}

Source: STATA 12 output for Hausman specification test 
As presented in table Hausman specification test was providing evidence in favor of the fixed effect model with p-value of 0.0000 which is less than $5 \%$ and this supports the fixed effects (FE) method is an efficient estimator for the panel data models.

\subsection{Regression analysis}

Table 3.9: Results of Regression Analysis

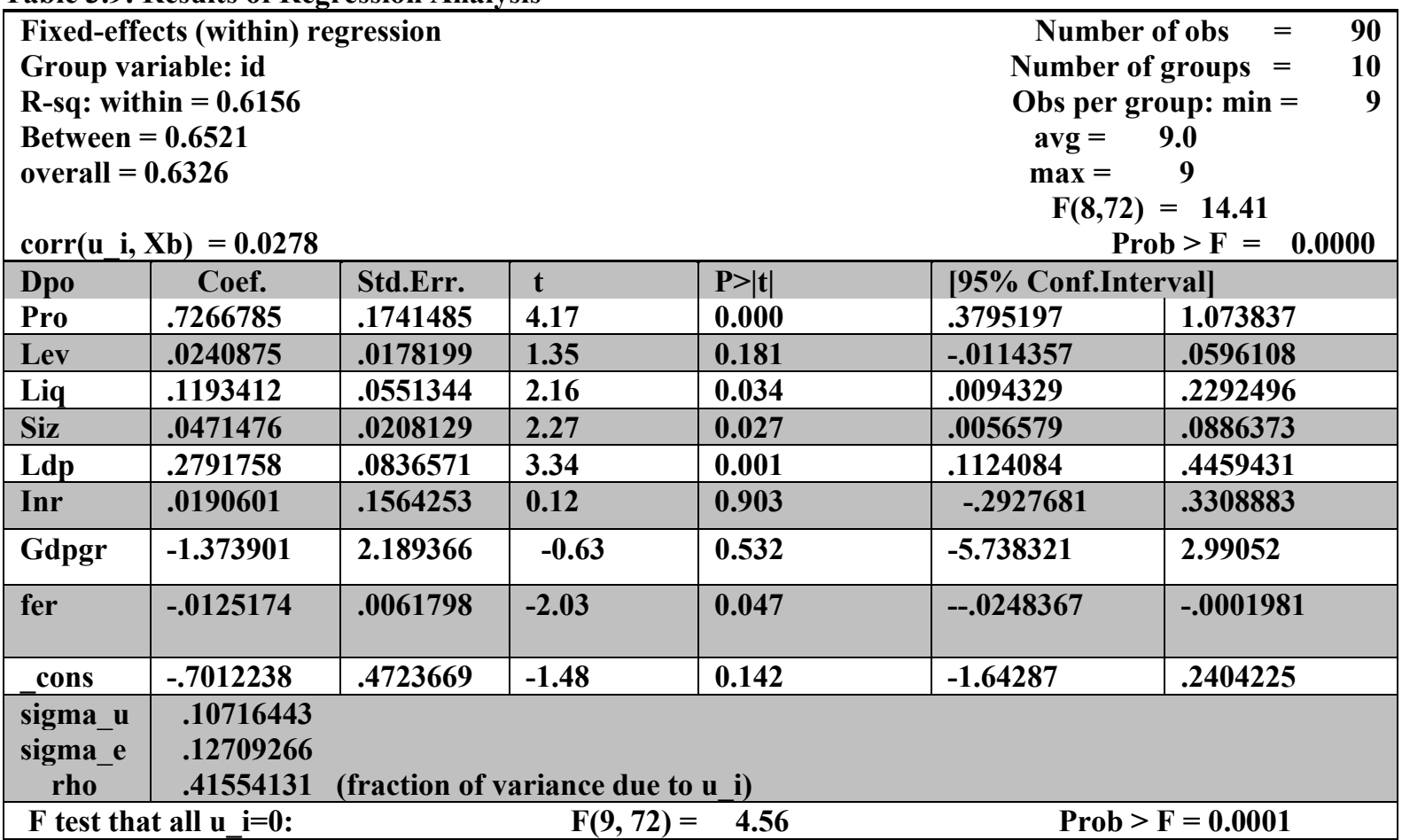

Source: STATA 12 output for fixed effect regression analyses

\subsection{Discussion}

\subsubsection{Profitability}

Profitability is found out as a significant explanatory variable for dividend payout at $5 \%$ significant level with pvalue of 0.0000 , which has a positive coefficient of .7266785. This indicates holding other things constant a 1 birr increase in profitability of banks will lead to a 72.66 cents increase in current dividend payout and the reverse is true.This finding is supported by the work of (Pruitt \& Gitman, 1991; Gill, et al., 2009; Muhammed, 2012 and Simegn, 2013)In the other side the results of this study is not consistent with the finding from(Ferris, et al., 2003; Al-Ajmi, 2008 and Theodros, 2011).The result is consistence with the researcher early expectation. Therefore the researcher haven't enough reason to reject hypothesis 1 stated as there is a significant positive relationship between profitability and dividend payout of private commercial banks in Ethiopia.

\subsubsection{Liquidity}

Liquidity has a positive and statistically significant relationship with dividend payout at $\mathrm{p}$ - value of 0.034 . The coefficient for liquidity is 0.1193412 . This indicates that holding other variables constant a 1 percent increase in liquidity leads to an increase by 0.12 percent to dividend payout of the sampled private commercial banks in Ethiopia and the reverse is also true.The result from this study is consistent with the researcher expectation. Therefore the researcher haven't got enough reason to reject hypothesis 3 , which stated that there is a significant positive relationship between liquidity and dividend payout private commercial banks in Ethiopia. The finding of this study is consistent to Theodros (2011) and the Jensen's (1986) agency theory which stated that companies with higher free cash flow have higher dividend payout ratios. In the other side there are also a number of studies that have showed a negative or insignificant relationship between liquidity and dividend payout (Imran, 2011; Kinfe, 2011; and Maladjian \& El Khoury, 2014).

\subsubsection{Bank size}

size is significant factor for dividend payout at $5 \%$ significant level with a $\mathrm{p}-$ value of 0.027 . The coefficient of bank size is 0.0471476 . This shows that holding other variables constant a one percent change in bank size leads about 0.047 percent changes in dividend payout of sampled private commercial banks in Ethiopia. The finding is consistent to the researcher's early expectations. Therefore there is no enough reason to reject the null hypothesis 4 , which states that there is a positive relationship between bank size and Ethiopian private banks dividend payout. 
The finding of this study is consistent with Theodros (2011) who found out firm size is statistically significant determinant of dividend policy. In the other side in contrary to this finding Elias (2015) suggests that firm size has a negative and statistically significant relationship with dividend payout. In addition to this Medhe et al. (2010) found out size is not a statistical significant factor for firm's dividend payout.

\subsubsection{Last year dividend}

last year dividend payout has a positive and statistically significant relationship with dividend payout at 5\% significance level with p- value of 0.001 . The coefficient for last year dividend is 0.2791758 . This indicates that holding other variables constant a 1 birr dividend paid in previous year will lead to a 27.9 cents increase in current dividend payout. This indicate that the sampled private commercial banks in Ethiopia paid a consistent dividend for their shareholders. Therefore the researcher haven't enough reason to reject the hypothesis 5 , stated that last year dividend has positive and significant relationship with dividend payout of private commercial banks in Ethiopia.The finding is consistent with Lintner, 1956; Bhattacharya, 1979; Javid, 2009; Theodros, 2011; Simegn, 2013 and Henok 2016) those researchers found out liquidity as a positive significant factor for dividend payout. It is also in line with signaling theory of dividend, where companies want to give a positive signal to the market that the company is in good condition by continuing paying dividends.

\subsection{5. foriegn exchange rate}

Foreign exchange rate has $\mathrm{p}$ - value of 0.047 . which indicates it is significant at $5 \%$ significance level. The coefficient of foreign exchange rate is -0.7012238 , which shows for one percent change in foreign exchange rate, keeping the other things constant will result -0.7012238 percent changes on dividend payout of sampled private commercial banks in opposite direction. The finding is consistent with the researcher's early expectation Therefore, the researcher haven't got enough reason to reject the predetermined hypothesis 8 , which states that there is a significant negative relationship between foreign exchange rate and dividend payout of private commercial banks in Ethiopia.The finding is consistent with Mundati(2013) who found out foreign exchange rate has a negative significant relationship with dividend payout.

\subsection{Conclusion}

The general objective of this paper is to investigate the determinant of private commercial banks dividend payout by using nine years balanced panel data set covering from 2009 to 2017 across 10 private commercial banks operating in Ethiopia. For this purpose bank specific variables that contain profitability ,leverage, liquidity, bank size and last dividend payout; and macroeconomic variables like inflation rate, real GDP growth rate and foreign exchange rate are incorporated as explanatory variables for dividend payout. To see the effects of the identified explanatory variables over the dependent variable (dividend payout), the researcher applied fixed effect panel data regression models and the results shows that all bank specific variables have a positive effect in determination of dividend payout of private commercial banks in Ethiopia.

In general from bank specific explanatory variables that are incorporated in this study profitability, liquidity, bank size and last year dividends are found out as a positive significant factor for dividend payout of private commercial banks in Ethiopia. However leverage is not a significant factor for dividend payout of private commercial banks in Ethiopia. From macroeconomic variables foreign exchange rate is found out as a significant variable but inflation and real GDP growth rate are not a significant variable for dividend payout of private banks in Ethiopia. Therefore, the major determinants of dividend payout of private commercial banks in Ethiopia are profitability, liquidity, bank size, last year dividends and foreign exchange rate.

\subsection{Recommendations}

In this part the researcher provides the possible recommendation for all stakeholders, those who should consider the result of this study including both actual and potential investors, Ethiopian private commercial banks and the regulatory body of Ethiopian government or national bank of Ethiopia. Based on the finding of this study the following recommendation is forwarded by the researcher to the above identified stakeholders.

* The finding related to profitability shows there is a positive significant relationship between profitability and dividend payout. Therefore it is better for private commercial banks, if they make an investement in profitable benture to earn higher profit and to pay a better dividend for their shareholders.

* The finding in relation to liquidity shows that it has a positive effect for dividend payout. This implies that shareholders expect more dividend from the banks that has higher liquidity position. Therfore it is better for the banks, if they maintain their liquidity position in order to be enough to pay higer dividend for their shareholders.

* The finding in relation to bank size shows there is a positive significant relationship between bank size and dividend payout. this indicates that the larger the bank size the more dividend payout in Ethiopian private commercial banks. So it is better for banks, if they pay dividends proportionally to their sizes.

* Last year dividend is found out as a significant factor for dividend payout and this shows that it is considered as a good signal for banks performance on the side of shareholders. Therefore, in order to 
keep their loyality on the side of their shareholders, it is better for Ethiopian private commercial banks, if they pay dividends consistently.

* Most of the time potential investors who want to invest in the banking sector are seeking information about the bank's profitability and dividend payout rate. But there are also other factors that should be considered in deciding the decision whether to invest or not in that particular bank. So it is better for those investors, if they understand the effect of other bank specific variables like liquidity, size and macro-economic factors like foreign exchange rate.

* The finding related to macro economic factors shows that exchange rate has a significant effect on dividend payout. So the government body,especially the financial sector regulatory body should consider the effect of macro-economic factors on dividend payout so as to make Ethiopian private commercial banks enough to pay dividends to their investors.

* In general the result of this study has identified the significant factors that affect the bank's dividend payout. Therefore, it is better if the management and bank's board of directors take consideration of those factors affecting dividend payout.

\section{Reference}

Ahmed, H \& Javid, A Y (2009), Determinants of dividend policy in Pakistan, International research journal of finance and economics, 29(1)

Al-Ajmi,J.\&Abu Hussein, H.(2011).Corporate dividend decisions: Evidence from Saudi Arabia, The Journal of Risk Finance, 12(1), 41-56.

Al-Kuwari, D. (2009). Determinants of the dividend policy in emerging stock exchanges: The case of GCC countries, Global Economy \& Finance Journal, Vol. 2 38-63.

Al-Kuwari, D. (2010). To pay or not to pay: Using emerging panel data to identify factors influencing corporate dividend payout decisions.International ResearchJournal of Finance \&Economics.

Al-Malkawi, N. Rafferty, M. \& Pillai, R. (2010). Dividend Policy: A Review of theories and empirical evidence. International Bulletin of Business Administration.

Al-Malkawi, N., (2007). Determinants of Corporate Dividend Policy in Jordan: An Application of the Tobit Mode 1. Journal of Economic \& Administrative Sciences, 23 (2): 44-70.

Amidu, M. \& Abor, J. (2006), Determinants of dividend payout ratios in Ghana, the Journal of Risk Finance, 7(2), 136-145.

Bhattacharya, S. (1979).The Bird in the Hand Fallacy.The Bell Journal of Economics, 10(1).

Bhattacherjee, A. (2012). Social Science Research: Principles, Methods, and Practices. University of South Florida.

Baker, H., \& Powell, G., (2000). Determinants of Corporate Dividend Policy: A Survey of NYSE Firms, Finance Pract Educ.

Brealey, R \& Myers, S. (2003), Principles of corporate finance'. New York: McGraw Hill.

Brealey, R. A. Myers, S. C. \& Allen, F. (2008),Principles of Corporate Finance. 9 ed. New York: Mc Graw-Hill Education.

Brigham, E. \& Houston, J (2004), Fundamental of Financial Management, 10th ed. Mc Graw-Hill.

Brooks, C.(2008), Introductory Econometrics for Finance,' (2 ed.), UK: Cambridge University Press.

Chekole, D., (2016). Internal Determinants of Dividend Payout in Private Commercial Banks in Ethiopia. Addis Ababa University, Ethiopia.

Collins, M. Saxena A. \& Wansley, J. (1996). The role of insiders and dividend policy: a comparison of regulated and unregulated firms, Journal of Finance Strategic.

Dahnani, (2005). Corporate Dividend Policy: The View of British Financial Managers. Journal of Business, Finance and Accounting, 60, pp. 3-43

Denis, L. Cristiano,A.\& Fernanda, M. (2015). Determinant Factors of Dividend Payments:Universidade Federal de Uberlândia, Faculdade de Gestão e Negócios, Uberlândia, MG, Brazil.

Easterbrook, F. H. (1984). Two Agency-Cost Explanations of Dividends. The American Economic Review, 74(4). Elias, S. (2015). Determinants of Dividend Payout in Ethiopian Private Banks. Addis Ababa University, Ethiopia Fama, E., \& French, K., (2001). Disappearing Dividends: Changing Firm Characteristics orLower Propensity to Pay, Journal of Financial Economics.

Ferris, S., Sen, N. and Yui, H. (2006). God save the queen and her dividends: corporate payouts in the UK.' Journal of Business

Gill, A. Biger, N. Pai, C. \& Bhutani, S. (2009). The Determinants of Capital Structure in the Service Industry: Evidence from Unite States. Open Bus Journal, 2, 48-53.

Gujarati, D. N. (2004). Basic Econometrics (4 ed.). The MacGraw-hill Companies

Henok, T. (2016), Internal Factors Influencing Dividend Payout of Ethiopian Insurance Companies, Addis Ababa University, Ethiopia. 
Higgins, R., (1981). The Corporate Dividend-Saving Decision, J Finance Quant Anal.

Gustav, H.\& Gairatjon , I. (2012). Determinants of Dividend Payout Ratios; A Study of Swedish Large and Medium Caps; A degree project. Sweden: Umeå School of Business and Economics.

Hutchinson, R. (1995). Corporate Finance. Cheltenham: Stanley Thorne Ltd.

Imran, K., (2011). Determinants of Dividend Payout Policy: A Case of Pakistan Engineering Sector. The Romanian Economic Journal.

Ishtiaq A. \& Muhammad F. (2016). Determinants of dividend payout policy: an empirical study of banking sector of Pakistan, University of Debrecen, Faculty of Economics \& Business.

Jensen, M. C. \& Meckling,W. H. (1976).Theory of the Firm: Managerial Behavior, Agency Costs and Ownership Structure. Journal of Financial Economics, 3(4),pp 305-360.

Jensen, G., Solberg, D.\& Zorn, T.,(1992), Simultaneous Determination of Insider Ownership, Debt, and Dividend Policies. Journal of Financial and Quantitative Analysis.

Kinfe, T. (2011). Determinants of Dividend payout: An Empirical Study on Bank Industry in Ethiopia, unpublished thesis submitted to Addis Ababa University in partial fulfillment of Masters of Accounting and Finance.

Kothari, C., (2004), Research Methodology, Methods and Techniques. 2nd ed. India: University Of Rajasthan.

Linter, J. (1956).Distribution of Incomes of Corporations among Dividends, Retained Earnings and Taxes. The American Economic Review, 46 (2): 97-113.

Liu, S. \& Hu, Y. (2005), Empirical Analysis of Cash Dividend Payment in Chinese Listed Companies, Nature and Science.

Lloyd, W., Jahera S., and Page D., (1985), Agency Cost and Dividend Payout Ratios, Q J Bus Econ.

Miller, M H. and Modigliani, F (1961), 'Dividend Policy, Growth, and the of Valuation Shares', Journal of Business Vol. 34,pp. 411-433.

Myers, S C. and Majluf N S. (1984),Corporate Financing and Investment Decisions When Firms Have Information that Investors Do Not Have, Journal of Financial Economics, Vol. 13, pp. 187-221

Mehdi M. , Mahdi S., \&Shahnaz H. (2010). Factors affecting dividend policy: Empirical evidence of iran, Preliminary communication.

Md. Zakir H.(2016) Determinants of the Dividend Payout Policy: A study on listed private commercial banks of Dhaka stock exchange limited in Bangladesh.

Mohamed, N., Hui W., Omar N., Rhamam R., \& Mastuki N., Zakaria S., (2006) Empirical Analysis of Determinist of Dividend Payment: Profitability and Liquidity, Accounting research instituteand Faculty of accountancy, Malaysia.

Muhammed, N. (2012). Determinants of Dividend Policy of Insurance Companies in Ethiopia, Addis Ababa University, Ethiopia.

Mueller, C., (1972). A Life Cycle Theory of the Firm, Journal of Industrial Economics', Vol-20 No.3, pp. 199219

Mundati, Z. (2013). The effects of macroeconomic variables on the dividend payout of firms listed at the Nairobi Securities Exchange, Unpublished MBA project, University of Nairobi.

National Bank of Ethiopia, (2017). Annual Report, Retrieved 30, 03, 2017, from National Bank of Ethiopia: www.nbe.gov.et

Ongeri, G 2014, "Determinants of dividend payout for companies listed at the Nairobi securities exchange", A Research project for Master of Science in Finance, University of Nairobi, School of Business.

Pandey, I.M.(2005), Financial management (9th Ed.).Delhi: Vikas Publishing House Pvt Ltd.

Pruitt, S. \& Gitman, L. (1991), The Interactions Between the Investment, Financing, and Dividend Decisions of Major US Firms, Finance Rev.

Okpara and Godwin Chigozie (2010), Adignosis of the determinants of dividend pay-out in Nigeria: A factor analytical approach, American journal of scientific research

Ross, S. A. (1977).The determination of financial structure: the incentive-signaling approach. The Bell Journal of Economics, 8(1), 23-40

Ross, S. A. Westerfield, R. W.\& Jaffe, J. F. (2002). Corporate Finance (6 ed., Vol. 1). New York, USA: McGrawHill/Irwin.

Simegn, H., (2013). Determinants of Dividend Policy of Banks in Ethiopia. Addis Ababa University, Ethiopia.

Theodros, K. (2011). Determinants of Dividend payout: An Empirical Study on Bank Industry in Ethiopia, Addis Ababa University, Ethiopia.

Watson, D.\& Head, A. (2010). Corporate Finance: Principles \& Practice (5 ed.). Pearson Education Limited.

Zikmund, W. G., Babin, B. J., Carr, J. C., \& Griffn, M. (2009),Business Research Methods (Eighth ed). 


\begin{tabular}{|c|c|c|c|c|c|}
\hline $\begin{array}{l}\text { Appendix } \\
\text { descriptive }\end{array}$ & & cs of collect & ted data & & \\
\hline Variable | & Obs & Mean & Std. Dev. & Min & Max \\
\hline dpo $\mid$ & 90 & .3625578 & .252958 & $\begin{array}{ll}0 & .8\end{array}$ & 3996975 \\
\hline pro & 90 & .2417521 & .1171031 & -.1303632 & 2.5823284 \\
\hline lev & 90 & .901583 & .8679757 & .0045529 & 8.884677 \\
\hline $\operatorname{liq} \mid$ & 90 & .8910957 & .4500407 & .0137874 & 1.942285 \\
\hline $\operatorname{siz}$ & 90 & 22.35046 & 1.393415 & 18.4116 & 24.46034 \\
\hline $\operatorname{ldp} \mid$ & 90 & .3392564 & .2552299 & $\begin{array}{ll}0 & .8\end{array}$ & 3996975 \\
\hline inr & 90 & .1551111 & .1133627 & .028 & .364 \\
\hline gdpgr & 90 & .1037778 & .0073252 & .087 & .114 \\
\hline fer & 90 & 19.87743 & 3.688774 & 13.5321 & 27.0321 \\
\hline
\end{tabular}

normality test and graph

Variable $\mid$ Obs Pr(Skewness) Pr(Kurtosis) adj chi2(2) Prob $>$ chi2

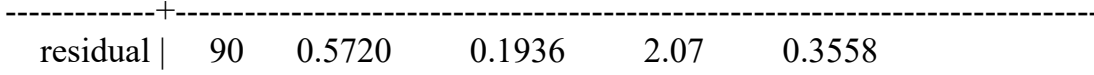

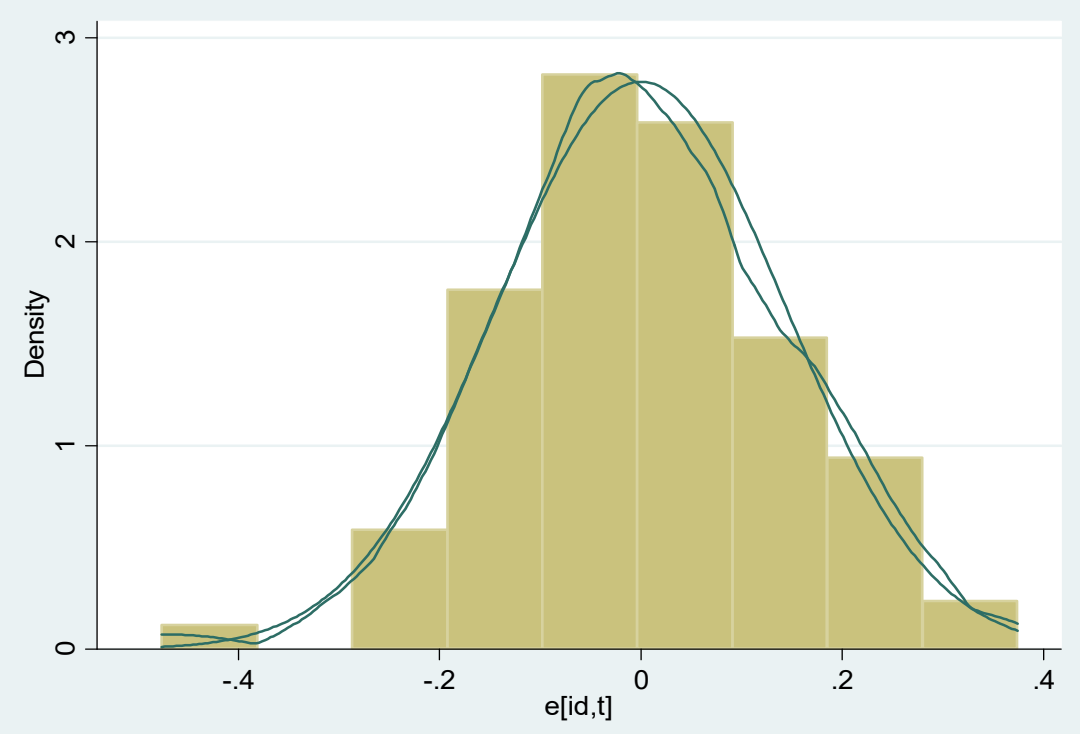

\section{Hetroskedasticity test}

Breusch-Pagan / Cook-Weisberg test for heteroskedasticity

Ho: Constant variance

Variables: fitted values of dpo

$\operatorname{chi} 2(1)=1.45$

Prob $>$ chi $2=0.2281$

\section{Breusch-Godfrey LM test for autocorrelation

\begin{tabular}{c|ccc}
$\operatorname{lags}(\mathrm{p})$ & $\mathrm{F}$ & $\mathrm{df}$ & Prob $>$ \\
1 & 0.945 & $(1,80)$ & 0.3338
\end{tabular}

H0: no serial correlation 
Correlation matrix between dependent and independent variables

| dpopro lev liq siz ldp inr gdpgr fer

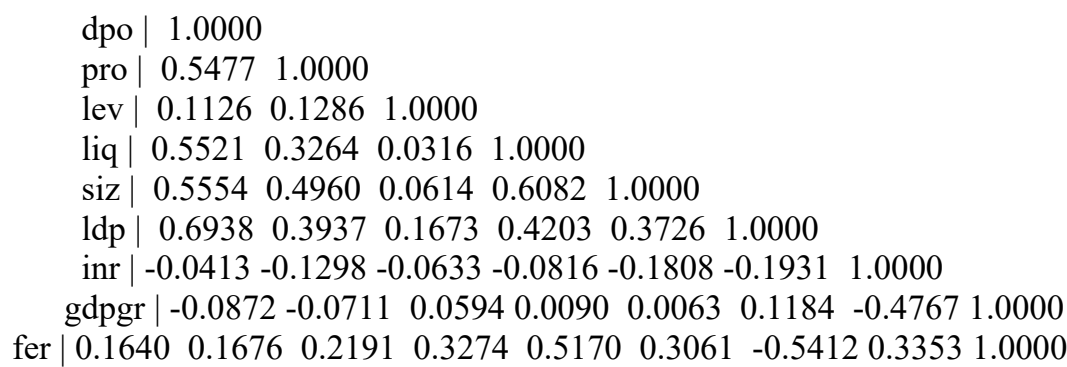

Correlation matrix between independent variables

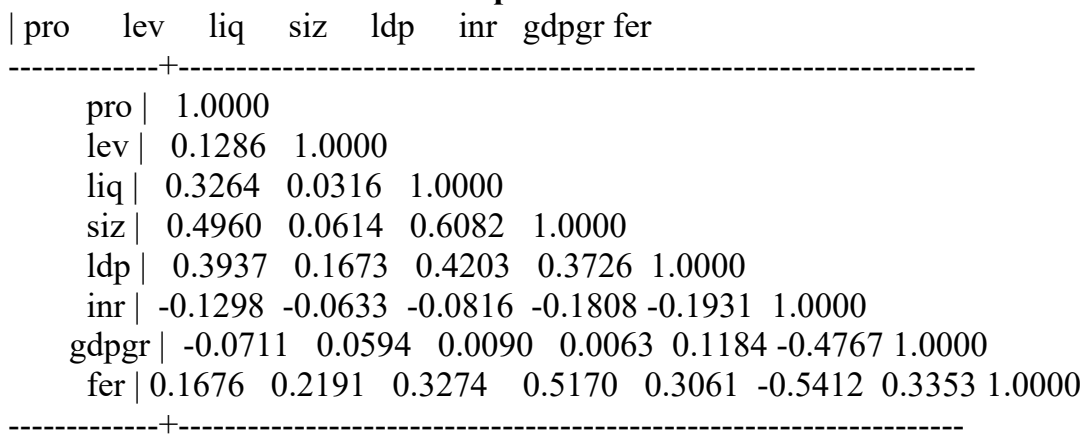

\section{hausman specification test}

\begin{tabular}{|c|c|c|c|c|}
\hline \multirow[b]{2}{*}{ | } & $\begin{array}{l}\text { (b) } \\
\text { (B) }\end{array}$ & nts ---- & \multicolumn{2}{|c|}{$\operatorname{sqrt}\left(\operatorname{diag}\left(\mathrm{V} \_b-V \_B\right)\right)$} \\
\hline & re & Difference & S.E. & \\
\hline pro & .7266785 & .3852308 & .3414477 & .1189461 \\
\hline lev & .0240875 & .0088412 & .0152463 & .0085523 \\
\hline $\operatorname{liq} \mid$ & .1193412 & .1013891 & .0179522 & .0456974 \\
\hline $\operatorname{siz}$ & .0471476 & .0490071 & -.0018595 & .0170114 \\
\hline $\operatorname{ldp}$ & .2791758 & .5086423 & -.2294666 & .0653782 \\
\hline inr & .0190601 & .0060781 & .012982 & .0177257 \\
\hline gdpgr & | -1.373901 & -2.452769 & 1.078869 & .474639 \\
\hline fer & -.0125174 & -.0139182 & .0014008 & .0036193 \\
\hline
\end{tabular}

$\mathrm{b}=$ consistent under Ho and $\mathrm{Ha}$; obtained from xtreg $\mathrm{B}=$ inconsistent under Ha, efficient under Ho; obtained from xtreg Test: Ho: difference in coefficients not systematic

$$
\begin{aligned}
& \text { chi2 }(5)=(b-B){ }^{\prime}\left[\left(V_{-} b-V_{-} B\right)^{\wedge}(-1)\right](b-B) \\
& \quad=28.83 \\
& \text { Prob }>\text { chi } 2=0.0000 \\
& \left(V \_b-V \_B \text { is not positive definite }\right)
\end{aligned}
$$




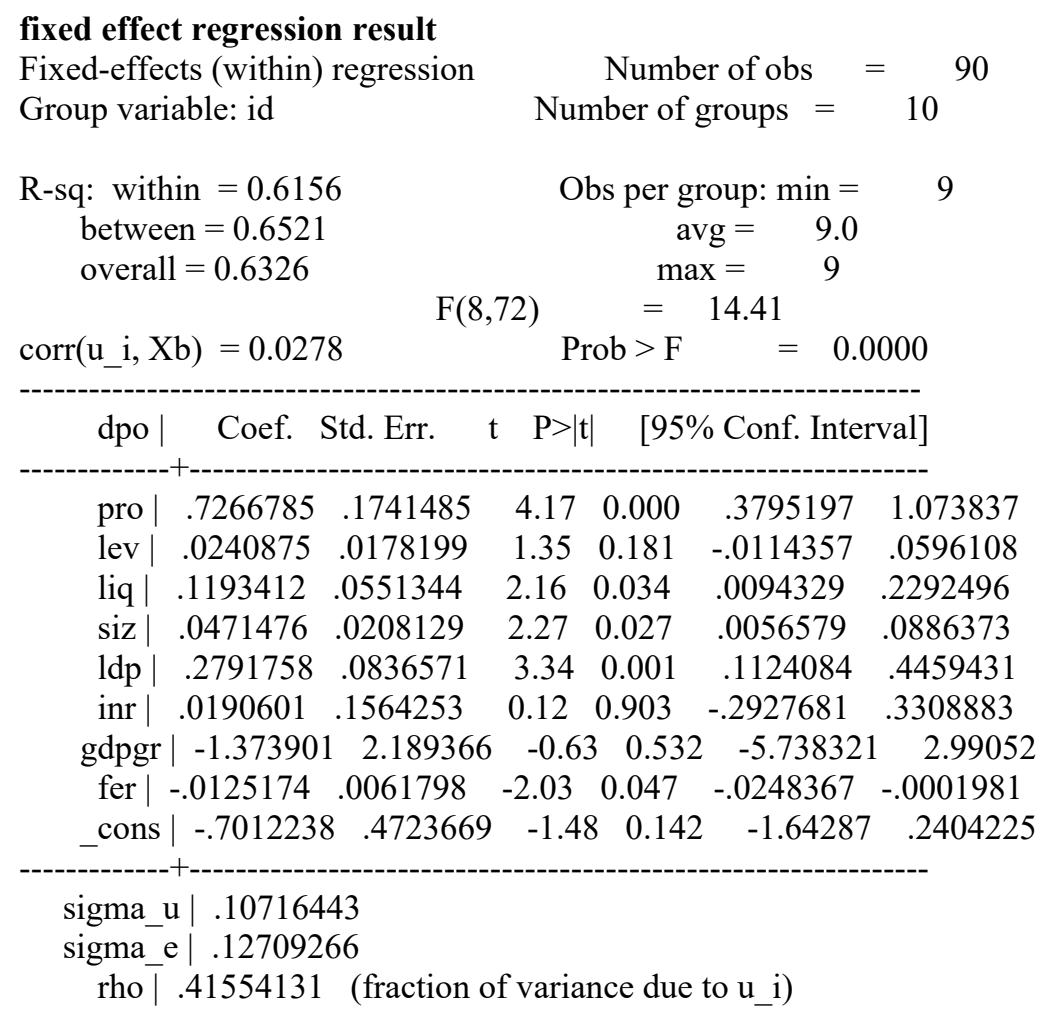

F test that all $u_{-} \mathrm{i}=0: \quad \mathrm{F}(9,72)=4.56 \quad$ Prob $>\mathrm{F}=0.0001$ 